\title{
THE RELATIONSHIP BETWEEN INTELLIGENCE AND GRADE POINT AVERAGE OF MEDICAL STUDY PROGRAM STUDENTS OF MEDICAL FACULTY OF MULAWARMAN UNIVERSITY
}

\author{
Andi Erika Safitri ${ }^{1 *}$, Eva Rachmi ${ }^{2}$, Sulistiawati $^{3}$ \\ ${ }^{1}$ Medical Study Program, Faculty of Medicine, University of Mulawarman, Indonesia \\ ${ }^{2}$ Anatomy Science Laboratory, Faculty of Medicine, University of Mulawarman, Indonesia \\ ${ }^{3}$ Medical Education Laboratory, Faculty of Medicine, University of Mulawarman, Indonesia \\ *E-mail: Andisafitri97@gmail.com
}

\begin{abstract}
A doctor is one of the professions in the health sector. To obtain this degree one must undergo medical education. Learning outcomes are obtained through 3P stages: presage, process, and products. Presage factors, including personal and situational. Personal factors have several components including intelligence. The purpose of this study was to determine the relationship of medical students' intelligence with their grade point average of the Medical Study Program of Medical Faculty the Mulawarman University. This study was an observational analytic study with the cross-sectional method. The data source is secondary data. The respondents were students of the Medical Study Program of the Medical Faculty of the Mulawarman University who met the inclusion criteria. Analysis with chi-square alternative test is Fisher's test. The study found that 305 respondents met the inclusion and exclusion criteria. Overall data of male respondents were 86 students (28.2\%) and female respondents were 219 students $(71.8 \%)$. Most intelligence students are on the average category of 131 students (43\%). The highest achievement index owned by respondents is on the Good category of 226 students (74.1\%). The overall results of the study were significant in $p=0.018$. For the grade IV is significant in $p=0.017$, grade III is significant in $p=$ 0.503 , grade II is significant in $p=1,000$, and grade $\mathrm{I}$ is significant in $\mathrm{p}=0.238$. The conclusion is that there is a correlation of intelligence with a grade point average (GPA). Among the grades, only grade IV has similar results.
\end{abstract}

Keywords: Intelligence, Grade Point Average (GPA), Medical Students

\section{INTRODUCTION}

A doctor is one of the professions engaged in the field of health. His/Her task is to solve public health problems. To get the degree, one must study through a medical education program. Medical education consists of two stages which must be carried out sequentially, the medical undergraduate stage and the medical profession stage. ${ }^{1}$ The medical undergraduate stage is important because, at this stage, students are primarily directed at the mastery of medical science. ${ }^{2}$ 
The Indonesian government facilitates a national examination of the competence of doctors to test their learning achievements after they complete the medical education program. The test is called the Student Competency Test for Medical Education Programs (UKMPPD). The goal of the program is to determine whether a doctor is nationally competent and standardized. It also is to assess the quality of medical education institutions in Indonesia. ${ }^{3}$ The result of the test, however, the UKMPPD failure rate from 2015 to 2018 was $41.8 \%, 43 \%, 48.5 \%$, and $39.2 \%$ respectively. The considerable percentage of UKMPPD failure is a concern to find the cause of the failure.

Learning Achievement (CP) is a formulation of educational goals and a statement of the quality of graduates. Therefore learning outcomes are an inseparable part of curriculum development in the study program. ${ }^{4}$ Although the learning outcomes are measured at the end of medical education through UKMPPD, it is very important to do periodic evaluations during the period of education so that learning can always be improved. ${ }^{5}$

In higher institutions, including at Mulawarman University, learning achievements can be noticed in the form of Achievement Index (IP) and Cumulative Achievement Index (IPK). IP is a measure of student academic ability based on the average weighting value of a particular semester. It is one form of learning achievement as of the results of the learning stages. Learning outcomes at every medical undergraduate stage relate to student performance at the medical profession stage.

Learning outcomes can be obtained through three stages of learning: presage, process, and product. The presage factor ought to be identified before the learning process is carried out. There are two factors included in the presage factor; personal factors and situational factors. There are some characters of personal factors that can influence the learning approach, including prior knowledge, abilities, intelligence, personality, and home background. Other factors are situational factors, such as the learning environment, teaching methods, and curriculum. The process factor consists of motivation and strategies that describe the way students implement and the reasons for doing the learning process. Product factors can be observed in the form of performance, one of them is academic achievement. ${ }^{7}$

There are several components of personal factors, one of which is intelligence. One way to measure intelligence is by measuring Intelligence Quotient (IQ). Biggs declares that intelligence influences learning outcomes. Other research, however, found that intelligence has no relationship with academic achievement ${ }^{8}$ or that intelligence has a weak relationship with academic achievement. ${ }^{9}$

Based on the background and theory that has been explained, there is a research gap found by researchers related to the relationship of intelligence and personality with the achievement index. Besides, there has never been an evaluation of psychological tests about intelligence if it has to do with the achievement index. Therefore researcher wants to prove whether there is a relationship between intelligence and personality to the achievement index in the Medical Study Program Students of the Medical Faculty of Mulawarman University. 


\section{MATERIAL AND METHOD}

This research is an analytic study using a cross-sectional design. It was conducted at the Faculty of Medicine at Mulawarman University. The research respondents were students of medical studies at the Faculty of Medicine, Mulawarman University. Selecting respondents in this study was conducted by a purposive sampling technique. The sample consisted of 305 students. They were obtained based on primary data collected by the researcher through secondary data obtained from the results of psychological tests. Students' achievement index is obtained during the odd semester of the 2018/2019 academic year. The Division of Student and Alumni and the division of Academic Affair of Medical Faculty Mulawarman facilitated the data. Data processing is performed using Microsoft Word 2016 software, Microsoft Excel 2016, and IBM SPSS 25.

\section{RESULT AND DISCUSSION}

This research was conducted at the Faculty of Medicine at Mulawarman University. Faculty of Medicine is one of the faculties with the accreditation of B, located on Jalan Krayan, Gn. Kelua, Samarinda Utara, Kota Samarinda, East Kalimantan. Data was collected on 27 March 2019-5 April 2019.

The students of Medical Study Program of the Medical Faculty of Mulawarman University consisted of 4 years; the freshmen (2018), the sophomore (2017), the junior (2016), and the senior (2015). Data collection is carried out in each class before or after carrying out expert lectures in the Lecture Room (RK) on the campus of the Medical Faculty of Mulawarman University.

Table 1 Characteristics of Respondents

\begin{tabular}{|c|c|c|}
\hline & $\begin{array}{l}\text { Amount } \\
(\mathrm{n}=305)\end{array}$ & $\begin{array}{l}\text { Percentage } \\
(\%)\end{array}$ \\
\hline \multicolumn{3}{|l|}{ Gender } \\
\hline - Males & 86 & 28.2 \\
\hline - Females & 219 & 71.8 \\
\hline \multicolumn{3}{|l|}{ Ages } \\
\hline - 17 years & 4 & 1.3 \\
\hline - 18 years & 43 & 14.1 \\
\hline - 19 years & 69 & 22.6 \\
\hline - 20 years & 86 & 28.2 \\
\hline - 21 years & 68 & 22.3 \\
\hline - 22 years & 31 & 10.2 \\
\hline - 23 years & 4 & 1.3 \\
\hline
\end{tabular}

The research has been conducted using analytic observational studies with cross-sectional methods. Research samples that met the inclusion and exclusion criteria were 305 from 314 students of the Medical Study Program, Faculty of Medicine, Mulawarman University. The 
primary data obtained from filling out the questionnaire. The secondary data facilitated bay the academic division as well as the student affairs and alumni of the Faculty of Medicine, University of Mulawarman.

Here are the characteristics of the respondents in the Medical Study Program of the Faculty of Medicine of Mulawarman University. Based on gender were 219 students (71.8\%). Based on the age of the respondents, most respondents in the Medical Study Program at the Medical Faculty of Mulawarman University was 20 years as many as 86 students $(28.2 \%)$.

Table 2 Frequency of the overall intelligence sample and each level

\begin{tabular}{lllllll}
\hline Intelligence quotient (IQ) & & & & \multicolumn{1}{c}{$\begin{array}{l}\text { Total } \\
\mathrm{n}(\%)\end{array}$} \\
$\begin{array}{l}\text { Border } \\
\text { Line } \\
\mathrm{n}(\%)\end{array}$ & $\begin{array}{l}\text { Dull } \\
\text { Average } \\
\mathrm{n}(\%)\end{array}$ & $\begin{array}{l}\text { Average } \\
\mathrm{n}(\%)\end{array}$ & $\begin{array}{l}\text { Superior } \\
\mathrm{n}(\%)\end{array}$ & $\begin{array}{l}\text { Very } \\
\text { Superior } \\
\mathrm{n}(\%)\end{array}$ & $\begin{array}{l}\text { Genius } \\
\mathrm{n}(\%)\end{array}$ & \\
\hline $4(1.3)$ & $10(3.3)$ & $\mathbf{1 3 1}(\mathbf{4 3})$ & $75(24.6)$ & $82(26.9)$ & $3(1)$ & $305(100)$
\end{tabular}

Note: bold letters are the highest number

IQ Range: Border Line "70-79", Dull Average "80-89", Average "90-109", Superior "110119", Very Superior "120-139", Genius " $\geq 140 "$

Here are the results of the 305 respondents of Medical Study Program students of the Faculty of Medicine of Mulawarman University. Most students are in the average category of 131 students (43\%). For each level, the highest level of level IV was very superior as many as 27 students (35.1\%). At level III, the average category was 34 students (46.6\%), at level II, the average category was 35 students $(43.8 \%)$, and the level I, the average category was 40 students $(53.3 \%)$. The variations in IQ among the students of the Medical Study Program at the Faculty of Medicine at Mulawarman University likely caused by heredity, environment, physical conditions such as nutritional conditions and physical development of each.10

Table 5 Frequency index of achievement index

\begin{tabular}{|c|c|c|c|c|c|}
\hline $\begin{array}{l}\text { GPA } \\
\text { Very } \\
\text { Good } \\
\mathrm{n}(\%)\end{array}$ & $\begin{array}{l}\text { Good } \\
\mathrm{n}(\%)\end{array}$ & $\begin{array}{l}\text { Fair } \\
\mathrm{n}(\%)\end{array}$ & $\begin{array}{l}\text { Poor } \\
\mathrm{n}(\%)\end{array}$ & $\begin{array}{l}\text { Very } \\
\text { Poor } \\
\text { n(\%) }\end{array}$ & $\begin{array}{l}\text { Total } \\
\mathrm{n}(\%)\end{array}$ \\
\hline $0(0)$ & $226(74.1)$ & $79(25.9)$ & $0(0)$ & $0(0)$ & $305(100)$ \\
\hline
\end{tabular}

Note: a bold letter is the highest number

GPA Range: Very Good "4.00", Good "3.00-3.99", Fair "2.00-2.99", Poor "1.00-1.99", Very Poor "0.00-0.99"

The highest achievement index owned by students of the Medical Study Program at the Faculty of Medicine at Mulawarman University is in the Good category of 226 students (74.1\%). Likewise, when analyzed at each level of achievement index, the Good category also becomes a good priority at level IV (63.6\%), level III (89\%), level II (91.3\%), and level I (52\%).

An achievement index is a form of learning model in the form of the product.7 Achievement index is also one of the learning achievements obtained by students after passing a certain period in an educational environment. This achievement index can be used by students as 
a material for self-evaluation so that in the future he can be even more active in understanding learning materials that ultimately get the expected achievement index.

Table 6 Results of cross tabulation between intelligence and overall achievement index and each level

\begin{tabular}{|c|c|c|c|c|c|c|c|c|}
\hline \multirow{3}{*}{$\begin{array}{l}\text { Students } \\
\text { Level }\end{array}$} & \multirow[t]{3}{*}{ Intelligence } & \multicolumn{4}{|l|}{ GPA } & \multicolumn{2}{|l|}{ Total } & \multirow[t]{3}{*}{ p-value } \\
\hline & & \multicolumn{2}{|l|}{ Good } & \multicolumn{2}{|l|}{ Fair } & \multirow[b]{2}{*}{$\mathrm{n}$} & \multirow[b]{2}{*}{$\%$} & \\
\hline & & $\mathrm{n}$ & $\%$ & $\mathrm{n}$ & $\%$ & & & \\
\hline \multirow[t]{6}{*}{ Overall } & $\mathrm{BD}$ & 2 & 50 & 2 & 50 & 5 & 100 & 0.018 \\
\hline & DA & 4 & 40 & 6 & 60 & 10 & 100 & \\
\hline & A & 91 & 69.5 & 40 & 30.5 & 131 & 100 & \\
\hline & $S$ & 58 & 77.3 & 17 & 22.7 & 75 & 100 & \\
\hline & VS & 68 & 82.9 & 14 & 17.1 & 82 & 100 & \\
\hline & $\mathrm{G}$ & 3 & 100 & 0 & 0 & 3 & 100 & \\
\hline \multirow[t]{5}{*}{ IV } & DA & 0 & 0 & 4 & 100 & 4 & 100 & 0.017 \\
\hline & A & 11 & 50 & 11 & 50 & 22 & 100 & \\
\hline & $S$ & 16 & 72.7 & 6 & 27.3 & 22 & 100 & \\
\hline & VS & 20 & 74.1 & 7 & 25.9 & 27 & 100 & \\
\hline & $\mathrm{G}$ & 2 & 100 & 0 & 0 & 2 & 100 & \\
\hline \multirow[t]{5}{*}{ III } & $\mathrm{BD}$ & 2 & 66.7 & 1 & 33.3 & 3 & 100 & 0.503 \\
\hline & DA & 4 & 80 & 1 & 20 & 5 & 100 & \\
\hline & A & 30 & 88.2 & 4 & 11.8 & 34 & 100 & \\
\hline & $S$ & 11 & 91.7 & 1 & 8.3 & 12 & 100 & \\
\hline & VS & 17 & 94.4 & 1 & 5.6 & 18 & 100 & \\
\hline \multirow[t]{3}{*}{$\overline{\text { II }}$} & A & 32 & 91.4 & 3 & 8.6 & 35 & 100 & 1.000 \\
\hline & S & 19 & 90.5 & 2 & 9.5 & 21 & 100 & \\
\hline & VS & 22 & 91.3 & 2 & 8.8 & 34 & 100 & \\
\hline \multirow[t]{5}{*}{ I } & $\mathrm{BD}$ & 0 & 0 & 1 & 100 & 1 & 100 & 0.238 \\
\hline & DA & 0 & 0 & 1 & 100 & 1 & 100 & \\
\hline & A & 18 & 45 & 22 & 55 & 40 & 100 & \\
\hline & $S$ & 12 & 60 & 8 & 40 & 20 & 100 & \\
\hline & VS & 9 & 69.2 & 4 & 30.8 & 13 & 100 & \\
\hline
\end{tabular}

Note: Thick lettered has a significance of $\mathrm{p} \leq 0.05$

: BD "Border Line", DA "Dull Average", A "Average", S "Superior", VS "Very Superior", G "Genius"

The relationship pattern was tested using Fisher's test analysis. The result is significant with a value of $0.018(p \leq 0.05)$. It can be interpreted that the hypothesis which states that there is a relationship between intelligence and achievement index is accepted. Fisher's test also reveals the relationship between intelligence and achievement index at the level I, II, III students. It respectively shows a significance level of p> 0.05 ie 0.238 at the level I, 1.000 at the level II, and 0.503 at the level III. This shows that the hypothesis stating there is a relationship between 
intelligence and achievement index is rejected for students of level I, II, and III. A different result is obtained for level IV students. The Fisher test suggests that the relationship between intelligence and achievement index showed a significance value of $0.017(\mathrm{p} \leq 0.05)$. This confirms that the hypothesis stating there is a relationship between intelligence and achievement index is accepted for level IV students.

Based on the analysis, the overall intelligence category is related to the achievement index. This is in line with the previous study that there is a positive correlation between IQ and Academic Achievement students in the Medical Faculty of Muhammadiyah University Palembang. This also is supporting the previous theory that the higher one's intelligence, the higher the learning achievement. The result also following the theory of Biggs (1987); that there are some general models of learning. In that model, several factors influence one's academic achievement. One of them is a personal factor in the form of intelligence. Another theory states that several factors affect the quality of learning, one of which is intelligence. The results of this study, however, are not in line with research on intelligence that has no relationship with academic achievement. It also is likely to cause intelligence has no relationship with the achievement index in this study because there are other types of intelligence that influence.

When examined at each level, only level IV students show the results that there is an intelligence relationship with the student achievement index of the Medical Studies Program at the Faculty of Medicine, Mulawarman University. This result is in line with previous research on 114 senior students of the Medical Faculty, University of Muhammadiyah Palembang. This latest study shows that the level of intelligence is related to the student's academic achievement index. Education is very contributory in providing a broader intellectual experience. Associated with the level of education related to the intellectual level will enable people to adapt to various conditions of life. This supports the results obtained in this study that intelligence in level IV students has a relationship with the achievement index. Thai why senior students must be able to adjust to a higher level of education.

\section{CONCLUSION}

Based on the results of the study, the conclusions are:

1. Overall, the Intelligence Quotient (IQ) of the students of the Medical Study Program at the Faculty of Medicine, Mulawarman University is on the average level.

2. Overall, the Achievement Index (IP) of the Medical Study Program students of the Medical Faculty of Mulawarman University is on good category with the range of 3.00-3.99.

3. There is the relationship between intelligence and the student achievement index of the Medical Study Program, Faculty of Medicine, Mulawarman University

\section{REFERENCES}

1. Konsil Kedokteran Indonesia. Standar Pendidikan Profesi Dokter Indonesia. Undang Undang Nomor 10 Tahun 2012. Sub bagian Pengertian Umum, Jakarta. / Konsil Kedokteran Indonesia. 2012. Standar Kompetensi Dokter Indonesia. Undang Undang Nomor 11 Tahun 2012. Sub bagian Pengertian Pendahuluan. Jakarta (2012). 
2. Undang Undang Republik Indonesia Nomor 20 Tahun 2013 Pendidikan Kedokteran. 6 Agustus 2013. Lembaran Negara Republik Indonesia Tahun 2013 nomor 132. Jakarta (2013).

3. Peraturan Menteri Riset, Teknologi, dan Pendidikan Tinggi (PERMENRISTEKDIKTI) Republik Indonesia Nomor 18 Tahun 2015 Tata Cara Pelaksanaan Uji Kompetensi Mahasiswa Program Profesi Dokter atau Dokter Gigi. 15 Juni 2015 Berita Negara Republik Indonesia Tahun 2015 Nomor 1012 (2015).

4. Kementrian Pendidikan dan Kebudayaan (MENDIKBUD). 2014. Panduan Penyusunan Capaian Pembelajaran Lulusan Program Studi . MENDIKBUD. Jakarta (2014).

5. Peraturan Menteri Riset, Teknologi, dan Pendidikan Tinggi (PERMEN RISTEKDIKTI) Republik Indonesia Nomor 44 Tahun 2015 Standar Nasional Pendidikan Tinggi. 21 Desember 2015. Berita Negara Republik Indonesia Tahun 2015 nomor 1952. Jakarta (2015).

6. Carr, S. E., Celenza, A., Puddey, I. B., \& Lake, F. (2014). Relationships between Academic Performance of Medical Students and their Workplace Performance as Junior Doctors. BMC Medical Education, 1-7 (2014).

7. Biggs, J. (1987). Students Approaches to Learning and Studying. Melbourne: Australian Council for Educational Research (1987).

8. Naderi, H., Abdullah, R., Aizan, T., \& Sharir, J. (2010). Intelligence and academic achievement: an investigation of gender differences. Life Science Journal, 7(1) (2010).

9. Kaur, N., Kaur, A., \& Kaur, J. Influence of Intelligence Quotient on the Academic Achievement of Students. International Journal of Advanced Research, 6(8), 541-548 (2018).

10. Mangiwa, R, Wungouw, H.I.S., Pangemanan, D.H.C. Kemampuan Intelligence Quotient (IQ) mahasiswa Fakultas Kedokteran Universitas Sam Ratulangi. Jurnal e-Biomedik, 2(3) (2014). 